\title{
Article \\ Creatine Monohydrate Supplementation Increases White Adipose Tissue Mitochondrial Markers in Male and Female Rats in a Depot Specific Manner
}

\author{
Chantal R. Ryan ${ }^{1} \mathbb{D}$, Michael S. Finch ${ }^{1}$, Tyler C. Dunham ${ }^{2}$, Jensen E. Murphy ${ }^{2}$, Brian D. Roy ${ }^{2} \mathbb{D}$ \\ and Rebecca E. K. MacPherson 1,*(D) \\ 1 Department of Health Sciences, Brock University, St. Catharines, ON L2S 3A1, Canada; \\ cr13ai@brocku.ca (C.R.R.); mf15kj@brocku.ca (M.S.F.) \\ 2 Department of Kinesiology, Brock University, St. Catharines, ON L2S 3A1, Canada; \\ td13nb@brocku.ca (T.C.D.); jm15ln@brocku.ca (J.E.M.); broy@brocku.ca (B.D.R.) \\ * Correspondence: rmacpherson@brocku.ca; Tel.: +1-905-688-5550
}

\section{check for}

updates

Citation: Ryan, C.R.; Finch, M.S.; Dunham, T.C.; Murphy, J.E.; Roy, B.D.; MacPherson, R.E.K. Creatine Monohydrate Supplementation Increases White Adipose Tissue Mitochondrial Markers in Male and Female Rats in a Depot Specific Manner. Nutrients 2021, 13, 2406. https://doi.org/10.3390/nu13072406

Academic Editors: Richard B. Kreider and Jeffrey R. Stout

Received: 26 May 2021

Accepted: 25 June 2021

Published: 14 July 2021

Publisher's Note: MDPI stays neutral with regard to jurisdictional claims in published maps and institutional affiliations.

Copyright: (c) 2021 by the authors. Licensee MDPI, Basel, Switzerland This article is an open access article distributed under the terms and conditions of the Creative Commons Attribution (CC BY) license (https:// creativecommons.org/licenses/by/ $4.0 /)$

\begin{abstract}
White adipose tissue (WAT) is a dynamic endocrine organ that can play a significant role in thermoregulation. WAT has the capacity to adopt structural and functional characteristics of the more metabolically active brown adipose tissue (BAT) and contribute to non-shivering thermogenesis under specific stimuli. Non-shivering thermogenesis was previously thought to be uncoupling protein 1 (UCP1)-dependent however, recent evidence suggests that UCP1-independent mechanisms of thermogenesis exist. Namely, futile creatine cycling has been identified as a contributor to WAT thermogenesis. The purpose of this study was to examine the efficacy of creatine supplementation to alter mitochondrial markers as well as adipocyte size and multilocularity in inguinal (iWAT), gonadal (gWAT), and BAT. Thirty-two male and female Sprague-Dawley rats were treated with varying doses $(0 \mathrm{~g} / \mathrm{L}, 2.5 \mathrm{~g} / \mathrm{L}, 5 \mathrm{~g} / \mathrm{L}$, and $10 \mathrm{~g} / \mathrm{L})$ of creatine monohydrate for 8 weeks. We demonstrate that mitochondrial markers respond in a sex and depot specific manner. In iWAT, female rats displayed significant increases in COXIV, PDH-E1alpha, and cytochrome $\mathrm{C}$ protein content. Male rats exhibited gWAT specific increases in COXIV and PDH-E1alpha protein content. This study supports creatine supplementation as a potential method of UCP1-independant thermogenesis and highlights the importance of taking a sex-specific approach when examining the efficacy of browning therapeutics in future research.
\end{abstract}

Keywords: adipose tissue; creatine; mitochondria; thermogenesis

\section{Introduction}

The activation of white adipose tissue (WAT) into a more metabolically active tissue has become a burning topic in obesity prevention and treatment. Today, WAT is no longer regarded as an inert storage depot for triacylglycerides, but is considered to be a highly plastic endocrine organ that can undergo dramatic phenotypic changes in response to different stresses (i.e., exercise, cold) [1-4]. Recently, there has been a large focus on the mechanisms by which WAT can be recruited to resemble the phenotypical and functional characteristics of the more metabolically active brown adipose tissue (BAT). This process is known as adipose tissue "browning" and results in the activation of beige adipocytes that reside in WAT depots [5]. Lineage tracing and molecular analysis indicates these beige adipocytes are distinct thermogenic fat cells [6], however beige adipocytes can convert to a WAT phenotype when the stimulus, such as cold exposure, is terminated [7], indicating that further work is necessary to fully distinguish white and beige adipocyte lineages. Considering the vast amount of WAT that individuals possess, the activation of WAT into the more metabolically active form of beige adipose tissue has the potential to significantly increase daily energy expenditure $[4,8]$. Thus, it could be regarded as a potential therapeutic treatment to combat the obesity epidemic and its related comorbidities. 
Morphologically, mature differentiated white adipocytes are described as unilocularcontaining a single large lipid droplet, few mitochondria, and a nucleus that has been pushed to the border of the cell membrane [9]. In contrast, brown adipose tissue (BAT) is described as multilocular with several smaller lipid droplets, a more central nucleus, and a dense population of mitochondria, ultimately giving the tissue its characteristic brown appearance [9]. Beige adipocytes lie along a continuum between WAT and BAT. The thermogenic capacity of brown and beige fat relies predominantly on a fatty acid/H+ symport mechanism mediated by uncoupling protein 1 (UCP1) [10-13]. This inner mitochondrial membrane protein stimulates thermogenesis by uncoupling the electron transport chain. Specifically, UCP1 dissipates the proton motive force and increases the rate of substrate flux through the mitochondrial electron transport chain [14]. This UCP1 dependent process is the most studied mechanism underlying the thermogenic capabilities of BAT, however, recently, UCP1-independent modes of thermogenesis have been uncovered.

In comparing the response of wildtype and UCP1 knockout mice to adrenergic stimulation, it was found that the thermogenic response (pharmacological and cold-induced) was similar [15-18], implying the presence of UCP1-independent thermogenic mechanisms. Previous work has found that reductions in high energy-phosphate compounds, such as creatine, result in a dysregulation of thermogenesis $[19,20]$ and a role for creatine cycling in adipose tissue thermogenesis was suggested almost four decades ago [1]. In 2015, Kazak et al. [14] performed quantitative mitochondrial proteomics and identified creatine metabolism as a signature of beige fat from cold-exposed mice. Interestingly, both genetic and pharmacological depletion of adipose creatine potentiates diet-induced obesity [21,22], and inactivation of creatine transport results in fat accumulation [21]. In adipose tissue, the creatine pool is regulated by intracellular synthesis and by influx from circulation. The forward and reverse phospho-transfer reactions of phosphocreatine (PCr)/creatine in most cells occur in a 1:1 stoichiometry with the ATP/ADP coupled. However, in thermogenic adipocytes, it has been estimated that there is an excessive release of ADP with respect to creatine $[14,23]$. Therefore, it is thought that creatine facilitates the regeneration of ADP through futile hydrolysis of PCr [14]. Importantly, it was recently demonstrated that creatine kinase $\mathrm{B}(\mathrm{CKB})$ traffics to the mitochondria where it plays an important role in the futile creatine cycle [24] and that tissue-nonspecific alkaline phosphatase (TNAP) localizes to the mitochondria where it acts as a robust $\mathrm{PCr}$ phosphatase in thermogenic fat [25]. Together, these studies demonstrate that adipocyte creatine energetics can be a key regulator of thermogenesis [14,20-23].

Creatine monohydrate $(\mathrm{CM})$ is a stable form of creatine with an attached molecule of water and is one of the most widely used and researched oral supplements (for review $[26,27]$. CM supplementation is well known for its effects on enhancing body composition, muscle mass and health, and exercise performance [28,29]. Supplementation is commonly in the range of 5 to $20 \mathrm{~g} /$ day which all lie within a range that is safe and tolerable for consumption $[27,30]$. While most of the work in the area has focused on CM supplementation and skeletal muscle outcomes, limited investigations have been performed to demonstrate that $\mathrm{CM}$ supplementation can increase creatine concentrations in other tissues. CM supplementation increases creatine concentrations in cardiac muscle, brain, kidney, liver, and lung tissue female rodents [31] — however, adipose tissue was not analyzed.

The purpose of the current investigation was to determine the effect of creatine supplementation on WAT browning in male and female Sprague-Dawley rats. To examine this question, male and female rats were separated into four different groups and supplemented with different doses of creatine $(0,2.5,5$ and $10 \mathrm{~g} / \mathrm{L})$ for 8 weeks. The results of this study provide novel information about the potential of creatine supplementation to induce WAT browning and further provide insight into the sex-specific responses of creatine supplementation. 


\section{Materials and Methods}

\subsection{Animals and Study Design}

Experimental protocols were approved by the Brock University Animal Care Committee (file \#19-02-01) and are in compliance with the Canadian Council on Animal Care. Thirty-two Sprague-Dawley rats (16 male, average body weight $372.4 \mathrm{~g} \pm 12.1 \mathrm{~g} ; 16$ female, average body weight $311.8 \mathrm{~g} \pm 21.0 \mathrm{~g}$ ) were ordered from Charles River Laboratories (Wilmington, MA, USA) at 11 weeks of age. Rats acclimatized for 7 days in the Brock University Comparative Biosciences Facility. All rats were kept on a 12-h light:12-h dark cycle and had ad libitum access to food (AIN-93G pellets) and water throughout the duration of the study. Rats were separated by sex, housed in pairs, and randomly assigned into one of four experimental groups: (1) control (1\% sucrose via drinking water), (2) $2.5 \mathrm{~g} / \mathrm{L}$, (3) $5 \mathrm{~g} / \mathrm{L}$, and (4) $10 \mathrm{~g} / \mathrm{L}$ of creatine monohydrate (CM) (Sigma-Aldrich; CAT\# C3630) and $1 \%$ sucrose via drinking water. Incremental doses of creatine monohydrate were selected to determine if there would be a dose response in adipose tissue adaptations. Rat weight, food, and water intake were measured three times a week for 8 weeks [32].

\subsection{Tissue Collection and Homogenization}

After the 8-week feeding period, rats underwent non-survival surgeries using isoflurane gas anesthesia. WAT samples were collected from inguinal subcutaneous fat depots (iWAT) and gonadal fat depots (gWAT; epididymal and ovarian), while BAT samples were collected from the interscapular fat pads. Samples were divided and placed in either formalin for histological analysis or snap frozen in liquid nitrogen and stored at $-80{ }^{\circ} \mathrm{C}$ for analysis via Western blotting. Blood samples were collected from the heart and rats were euthanized via exsanguination.

\subsection{Western Blotting}

Samples were homogenized via FAST prep (FastPrep ${ }^{\circledR}$, MP Biomedicals, Santa Ana, CA, USA) in 3 and 10 volumes (WAT and BAT samples respectively) of NP40 Cell Lysis Buffer (Life Technologies; CAT\# FNN0021) supplemented with $34 \mu \mathrm{L}$ phenylmethylsulfonyl fluoride and $50 \mu \mathrm{L}$ protease inhibitor cocktail (Sigma; CAT\# 7626-5G, CAT\# P274-1BIL). Homogenates were then centrifuged at $4{ }^{\circ} \mathrm{C}$ for $5 \mathrm{~min}$ at $1500 \times \mathrm{g}$, after which the infranatant was collected and protein concentration was determined using a Bicinchoninic acid assay (Sigma-Aldrich-B9643, VWR-BDH9312). Homogenates were prepared in $2 \times$ Laemmli sample buffer $(1 \mu \mathrm{g} / \mu \mathrm{L})$ and were denatured at $100{ }^{\circ} \mathrm{C}$ for $5 \mathrm{~min}$. Equal amounts of sample (10-20 $\mu \mathrm{g})$ were loaded to undergo protein separation via SDS-PAGE ( $4 \%$ stacking, $10-15 \%$ resolving gel) for $90 \mathrm{~min}$ at $120 \mathrm{~V}$ ). Protein was wet transferred to $0.45 \mu \mathrm{m}$ nitrocellulose membranes (CAT\# 10600001, Milipore Sigma Burlington, MA, USA) at $100 \mathrm{~V}$ for $60 \mathrm{~min}$. Membranes were blocked in tris buffered saline/ $0.1 \%$ tween 20 (TBST) prepared with $5 \%$ non-fat dry milk for $1 \mathrm{~h}$ followed by overnight incubation at $4{ }^{\circ} \mathrm{C}$ with the appropriate primary antibody. Following primary incubation, membranes were rinsed with TBST and incubated with the appropriate Horseradish peroxidase-conjugated secondary antibodies for $1 \mathrm{~h}$ at room temperature. Ponceau staining was used to confirm equal protein loading $(<10 \%$ variability across the membrane). Signals were detected using enhanced chemiluminescence (Western Lightening ${ }^{\circledR}$ Plus ECL, Perkin Elmer, MA, USA) and were subsequently quantified by densitometry using a FluorChem HD imaging system (Alpha Innotech, Santa Clara, CA, USA). The primary antibodies included: cytochrome C (ABCAM, CAT\# ab76237), citrate synthase (ABCAM, CAT\# ab96600), COXIV (Molecular Probes, CAT\# A-21348), PDH (Millipore, CAT\# ABS2082), UCP-1 (ABCAM, CAT\# ab10983), PGC-1 $\alpha$ (Millipore, CAT\# AB3242), GAMT (ABCAM, CAT\# ab126736), and CKB (Abclonal; cat. no. ab12631). 


\subsection{Real-Time $q P C R$}

Adipose mRNA was extracted and reverse transcribed into cDNA and changes in mRNA expression were determined using real-time quantitative PCR as described previously [33]. RNA was isolated from adipose tissue following homogenization in Trizol reagent using an RNeasy kit according to the manufacturer's instructions (RNeasy Kit 74106; Qiagen). RNA yield and purity were determined using a Nano-drop system (NanoVue plus; GE healthcare). RNA samples were prepared at $1 \mu \mathrm{g} / \mu \mathrm{L}$ using RNase free water. cDNA was synthesized using random primers and dNTP (Invitrogen) at a 1:1 ratio as well as a master mix ( $5 \times$ FSB, DTT, RNase out and SuperScript II Reverse Transcriptase). 7500 Fast Real-Time PCR system (Applied Biosystems) was used to perform the RT qPCR. Samples were loaded in duplicate and contained $10 \mu \mathrm{L}$ of PCR master mix, $4 \mu \mathrm{L}$ of RNase free water, $1 \mu \mathrm{L}$ of gene expression assay, and $5 \mu \mathrm{L}$ of cDNA. Gene expression assays were purchased for Slc6a8 (Rn00506029_mL). Gapdh was used as a housekeeping gene and was not different between groups. Relative differences in $S l c 6 a 8$ were determined using the $2^{-\Delta \Delta \mathrm{CT}}$ method and normalized to the respective control group [34].

\subsection{Histology}

Samples (gWAT, iWAT, and BAT) underwent fixation in 10\% neutral buffered formalin (Millipore Sigma, CAT\#HT501128) for $62 \mathrm{~h}$. Following fixation, samples were transferred into $70 \%$ ethanol for future processing. Samples underwent dehydration via ethanol $(1 \times 90 \% 30 \mathrm{~min}, 3 \times 100 \% 40 \mathrm{~min})$ and xylene (Fischer Scientific) $(3 \times 45 \mathrm{~min})$. Samples were embedded in paraffin and $10 \mu \mathrm{m}$ sections were mounted on $1.2 \mathrm{~mm}$ Superfrost ${ }^{\mathrm{TM}}$ slides. Slides were stained with Harris hematoxylin and eosin (H\&E), imaged using a Nikon Eclipse 80i microscope (CAT\#PL-D655CU-CYL), and images were captured with Pixelink software. Three images from each animal ( 150 cells/image) were sampled to determine cross-sectional area and percent multilocular (ImageJ software, National Institute of Mental Health, Bethesda, MD, USA).

\subsection{Statistical Analysis}

Control male and female comparisons were made with a one-way analysis of variance (ANOVA). Comparisons within sex and across doses were made with a one-way ANOVA with all measurements being made relative to the control groups. Post-hoc analysis was completed with a Tukey's multiple comparisons test. Statistical significance was assumed at $p \leq 0.05$, and GraphPad Prism 8 software (GraphPad Software, La Jolla, CA, USA) was used to perform all statistical analyses. Results are stated and presented as mean $\pm \mathrm{SEM}$ for all groups.

\section{Results}

\subsection{Animal and Adipose Tissue Depot Characteristics}

No differences were observed for male or female rat body mass at the end of the intervention between creatine doses. Female rats had a lower body mass compared to males in each creatine supplementation group $(p<0.05)$. Food and water intake were not different for either male or female rats in each creatine supplementation group. Normalizing for body mass, female rats ate more when compared to males in each treatment group $(p<0.05)$. Total creatine consumption relative to body mass was different between doses for both male and female rats. Relative creatine consumption was higher in the $2.5 \mathrm{~g} / \mathrm{L}(p=0.001)$, $5 \mathrm{~g} / \mathrm{L}(p<0.001)$, and $10 \mathrm{~g} / \mathrm{L}(p<0.001)$ groups compared to the control group. Compared to the $2.5 \mathrm{~g} / \mathrm{L}$ group, the $5 \mathrm{~g} / \mathrm{L}(p=0.005)$ and $10 \mathrm{~g} / \mathrm{L}(p<0.001)$ groups had higher relative creatine consumption. The $10 \mathrm{~g} / \mathrm{L}$ group consumed more creatine relative to bodyweight than the $5 \mathrm{~g} / \mathrm{L}$ group $(p<0.001)$. No differences were observed across treatment groups for male or female adipose tissue protein content (ug protein/mg tissue; Table 1). Using rat weights and water consumption data, it is estimated that rats consumed $0.22 \mathrm{~g} / \mathrm{kg} /$ day ( $2.5 \mathrm{~g} / \mathrm{L}$ group), $0.41 \mathrm{~g} / \mathrm{kg} /$ day $(5 \mathrm{~g} / \mathrm{L}$ group), and $0.79 \mathrm{~g} / \mathrm{kg} /$ day $(10 \mathrm{~g} / \mathrm{L}$ group) with no difference in relative creatine intake between sexes. The Human Equivalent Dose based on 
body surface area adjustments [35] suggests that these doses would be equivalent to 2.5, 4.7 , and $9.0 \mathrm{~g} /$ day in a 7-kg human-normal ranges of CM supplementation.

Table 1. Animal and adipose depot characteristics.

\begin{tabular}{|c|c|c|c|c|}
\hline \multicolumn{5}{|c|}{ Animal Characteristics } \\
\hline Creatine $\left(\mathrm{g} \cdot \mathrm{L}^{-1}\right)$ & 0 & $2.5^{\$}$ & $5 \&$ & 10 \\
\hline \multicolumn{5}{|c|}{ End point body mass (g) } \\
\hline Males & $587.8 \pm 9.1$ & $602.8 \pm 14.1$ & $610.3 \pm 25.3$ & $584.5 \pm 23.0$ \\
\hline Females & $376.8 \pm 13.5^{*}$ & $416.3 \pm 13.5 *$ & $397.0 \pm 7.1^{*}$ & $404.8 \pm 28.3^{*}$ \\
\hline \multicolumn{5}{|c|}{ Food Intake $\left(\mathrm{g} \cdot \mathrm{day}^{-1}\right)$} \\
\hline Males & $24.4 \pm 0.3$ & $24.3 \pm 0.9$ & $23.7 \pm 1.7$ & $23.8 \pm 1.3$ \\
\hline Females & $17.7 \pm 1.2 *$ & $19.0 \pm 0.7^{*}$ & $18.3 \pm 0.1 *$ & $18.75 \pm 1.2 *$ \\
\hline \multicolumn{5}{|c|}{ Water Intake $\left(\mathrm{mL} \cdot\right.$ day $\left.^{-1}\right)$} \\
\hline Males & $57.9 \pm 14.0$ & $44.9 \pm 8.7$ & $36.1 \pm 2.2^{\#}$ & $43.5 \pm 1.0$ \\
\hline Females & $34.7 \pm 4.6^{*}$ & $35.8 \pm 5.4^{*}$ & $35.4 \pm 1.9^{*}$ & $27.9 \pm 1.3^{*}$ \\
\hline \multicolumn{5}{|c|}{ Gonadal Adipose Tissue Protein Content (ug protein/mg tissue) } \\
\hline Males & $19.4 \pm 1.3$ & $19.4 \pm 1.2$ & $18.2 \pm 0.3$ & $19.1 \pm 1.3$ \\
\hline Females & $19.5 \pm 1.0$ & $18.0 \pm 1.1$ & $18.1 \pm 0.3$ & $18.1 \pm 0.7$ \\
\hline \multicolumn{5}{|c|}{ Inguinal Adipose Tissue Protein Content (ug protein/mg tissue) } \\
\hline Males & $28.2 \pm 1.2$ & $27.5 \pm 3.9$ & $33.9 \pm 6.0$ & $29.0 \pm 0.9$ \\
\hline Females & $29.0 \pm 4.6$ & $25.1 \pm 1.0$ & $29.8 \pm 1.7$ & $29.9 \pm 0.9$ \\
\hline \multicolumn{5}{|c|}{ Interscapular Brown Adipose Tissue Protein Content (ug protein/mg tissue) } \\
\hline Males & $93.4 \pm 5.4$ & $111.6 \pm 12.2$ & $99.6 \pm 9.4$ & $107.2 \pm 10.8$ \\
\hline Females & $112.0 \pm 9.4$ & $106.3 \pm 12.2$ & $117.2 \pm 7.6$ & $120.9 \pm 3.1$ \\
\hline
\end{tabular}

End point body mass, total food intake, water intake, and creatine intake. Data are presented as means $\pm \mathrm{SD}$

${ }^{*} p<0.05$ compared to males in the same treatment group. ${ }^{\#} p<0.05$ compared to control of same sex. ${ }^{\$} p<0.05$ compared to $2.5 \mathrm{~g} / \mathrm{L}$ group of same sex. ${ }^{\&} p<0.05$ compared to $5 \mathrm{~g} / \mathrm{L}$ group of same sex.

\subsection{Creatine Supplementation Increases Mitochondrial Markers in Female Rat Inguinal White} Adipose Tissue

Female rats had lower PDH-E1 alpha and citrate synthase protein content in inguinal subcutaneous adipose tissue when compared to male rats ( $p<0.05$; Figure 1A). Creatine supplementation did not alter mitochondrial protein content in male rat inguinal subcutaneous adipose tissue (Figure 1B). In female rats, creatine supplementation resulted in a higher COVIX (5 g/L), PDH-E1alpha $(2.5 \mathrm{~g} / \mathrm{L}, 5 \mathrm{~g} / \mathrm{L}$, and $10 \mathrm{~g} / \mathrm{L})$, and cytochrome C $(10 \mathrm{~g} / \mathrm{L})$ content compared to control females $(p<0.05$; Figure 1B). No differences were observed in UCP1 content in male or female rats (Figure 1C). No differences were observed for male or female adipocyte area or $\%$ multilocular in the $10 \mathrm{~g} / \mathrm{L}$ creatine supplemented group compared to control (Figure 1D). 


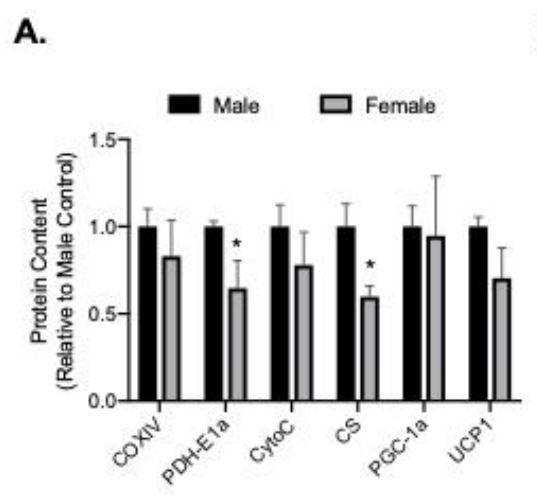

B. Females
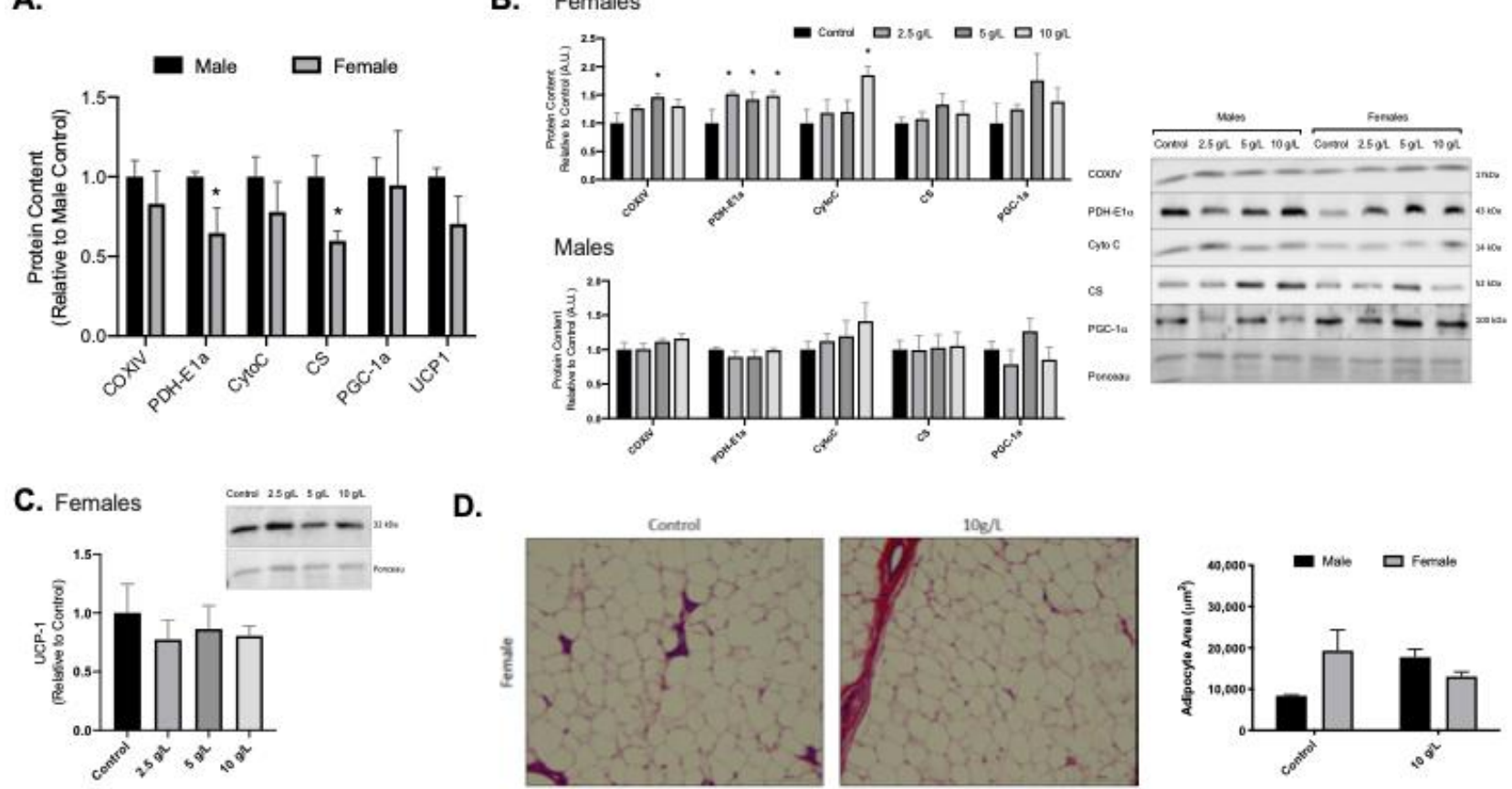

D.
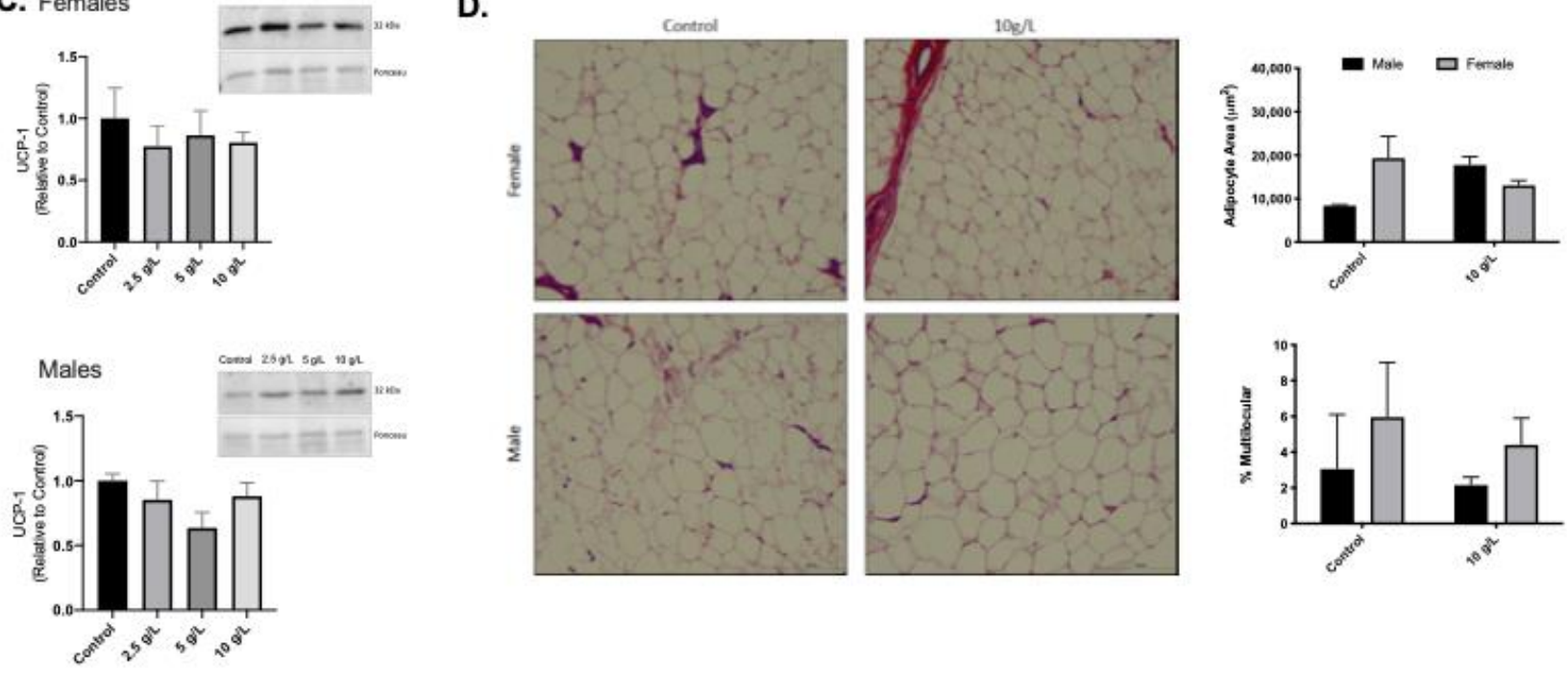

Figure 1. Subcutaneous inguinal white adipose tissue (iWAT) mitochondrial protein content and morphology. (A) Quantified Western blot data for iWAT protein content of COXIV, PDH-E1 $\alpha$, Cytochrome C (Cyto C), citrate synthase (CS), PGC-1 $\alpha$, and uncoupling protein-1 (UCP1) for control male and female rats. (B) Quantified Western blot data for mitochondrial proteins across creatine supplemented groups and representative Western blot images. (C) UCP-1 content in male and female rats across creatine supplemented groups. (D). Representative images of H\&E stained slides. Scale bar on H\&E representative image represents $100 \mu \mathrm{m}$. Data were analyzed by ANOVA and are presented as mean $\pm \mathrm{SEM},{ }^{*}$ denotes significantly different from control group, $p<0.05$.

\subsection{Creatine Supplementation increases Mitochondrial Markers in Male Rat Gonadal White Adipose Tissue}

Female rats had lower PGC-1alpha content in gonadal visceral adipose tissue compared to male rats $(p<0.05$; Figure $2 \mathrm{~A})$. Creatine supplementation did not alter mitochondrial protein content in female rat gonadal visceral adipose tissue (Figure 2B). In male rats, creatine supplementation resulted in a higher COXIV content $(10 \mathrm{~g} / \mathrm{L}$ vs. all other groups, $p<0.05)$ and PDH-E1alpha content $(10 \mathrm{~g} / \mathrm{L}$ vs. control and $2.5 \mathrm{~g} / \mathrm{L}$, and $5 \mathrm{~g} / \mathrm{L}$ vs. 2.5 $\mathrm{g} / \mathrm{L}, p<0.05$ ) (Figure 2B). No differences were observed for male or female adipocyte area (Figure 2C). Control male rats had higher \% multilocular adipocytes compared to control females (Figure 2C). No differences in \% multilocular adipocytes were observed in the 10 $\mathrm{g} / \mathrm{L}$ creatine supplemented group compared to control or between sexes (Figure 2C). 
A.

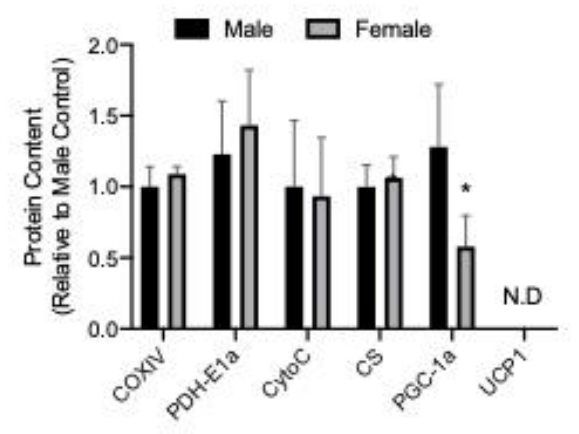

C.
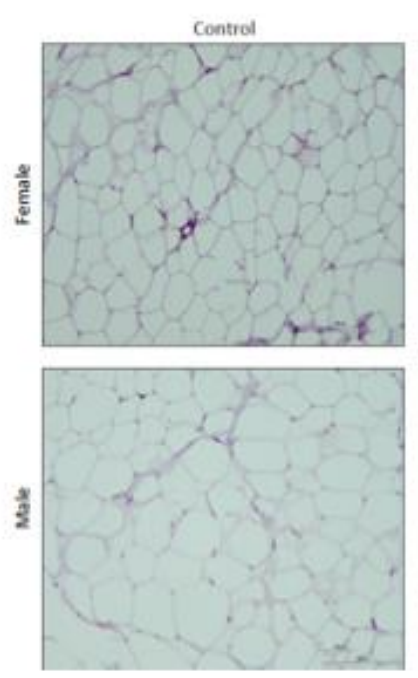

B. Females



Males

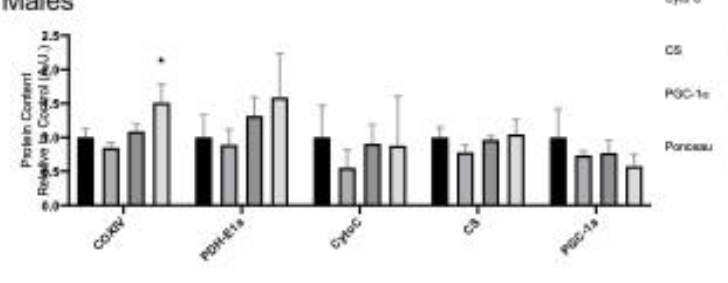

Figure 2. Visceral gonadal white adipose tissue (gWAT) mitochondrial protein content and morphology. (A) Quantified Western blot data for gWAT protein content of COXIV, PDH-E1 $\alpha$, Cytochrome C (Cyto C), citrate synthase (CS), PGC- $1 \alpha$, and uncoupling protein-1 (UCP1) for control male and female rats. (B) Quantified Western blot data for mitochondrial proteins across creatine supplemented groups and representative Western blot images. (C) Representative images of H\&E stained slides. Scale bar on H\&E representative image represents $100 \mu \mathrm{m}$. Data were analyzed by ANOVA and are presented as mean $\pm \mathrm{SEM},{ }^{*}$ denotes significantly different from control group, $p<0.05$.

3.4. Creatine Supplementation does Not increase Mitochondrial Markers Brown Adipose Tissue in either Male or Female Rats

Female rats displayed higher PGC-1alpha content compared to male rats (Figure 3A). Creatine supplementation did not alter mitochondrial protein content in either male or female BAT at any of the supplemented doses (Figure 3B, $p<0.05$ ). No differences were observed for UCP1 content in male or female rats across all creatine supplemented groups (Figure 3C). No differences were observed for male or female adipocyte area or \% multilocular in the $10 \mathrm{~g} / \mathrm{L}$ creatine supplemented group compared to control (Figure 3D). 
A.

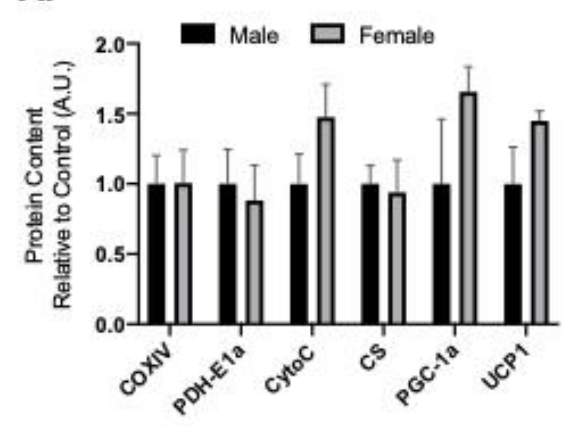

B. Females

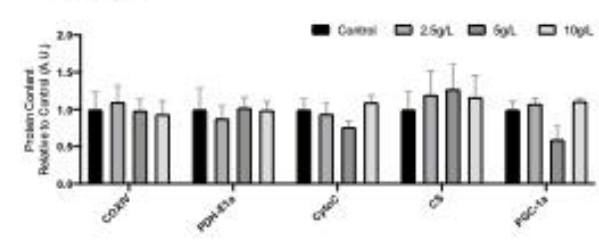

Males



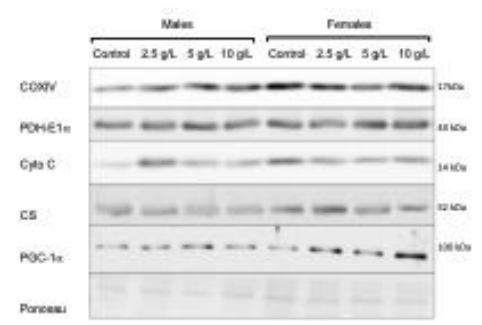

C. Females
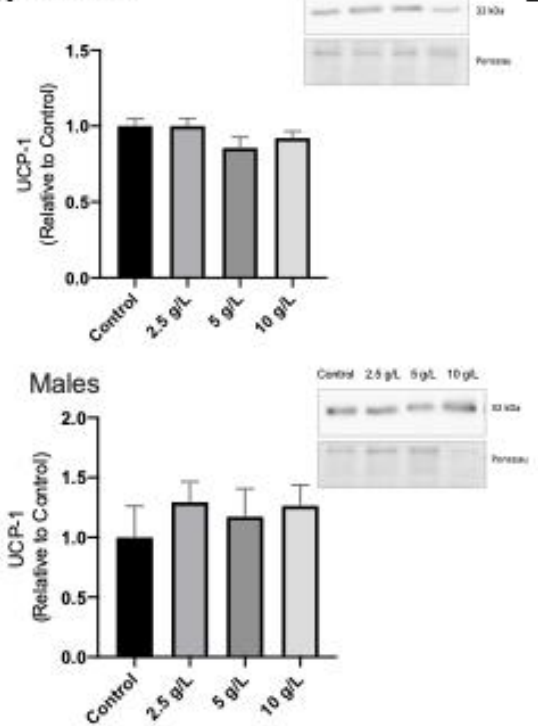

D.
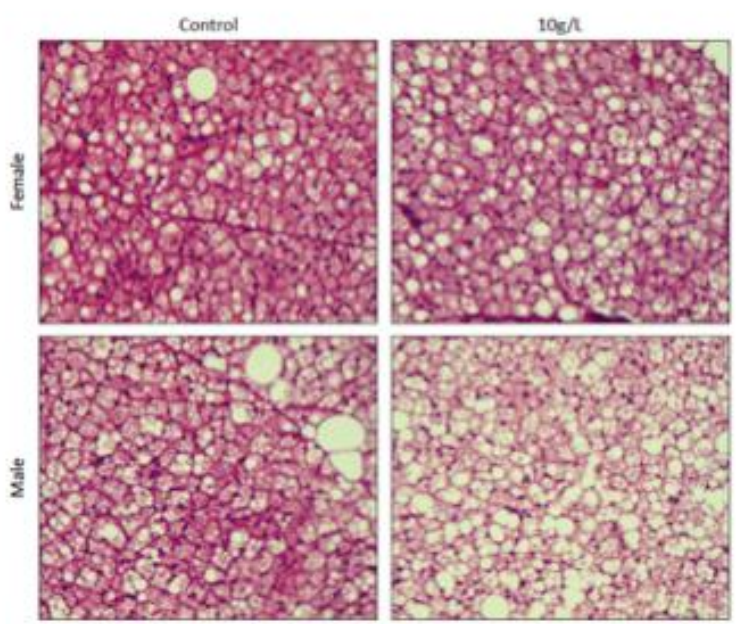

Figure 3. Brown adipose tissue (BAT) mitochondrial protein content and morphology. (A) Quantified Western blot data for BAT protein content of COXIV, PDH-E1 $\alpha$, Cytochrome C (Cyto C), citrate synthase (CS), PGC- $1 \alpha$, and uncoupling protein-1 (UCP1) for control male and female rats. (B) Quantified Western blot data for mitochondrial proteins across creatine supplemented groups and representative Western blot images. (C) UCP-1 content in male and female rats across creatine supplemented groups. (D) Representative images of H\&E stained slides. Scale bar on H\&E representative image represents $100 \mu \mathrm{m}$. Data were analyzed by ANOVA and are presented as mean $\pm \mathrm{SEM}$, denotes significantly different from control group, $p<0.05$.

\subsection{Creatine Supplementation Alters Markers of Creatine Uptake and Metabolism}

Examination of GAMT protein content, a catalyst enzyme responsible for mediating intrinsic creatine synthesis, revealed no differences for GAMT content across any of the creatine dosages or sexes (Figure 4A). CKB was analyzed as a marker of creatine cycling. $\mathrm{CKB}$ content was higher in female iWAT at $5 \mathrm{~g} / \mathrm{L}$ compared to control, this did not reach significance in the $10 \mathrm{~g} / \mathrm{L}$ group. There were no differences observed in the other depots and no differences observed in the male samples (Figure 4B). As a marker of alterations in creatine transport, Slc6a8 expression was examined. Slc6a8 expression was higher in gWAT of female rats treated with $10 \mathrm{~g} / \mathrm{L}$ creatine compared to controls with no differences in the other adipose depots (Figure $4 \mathrm{C}$ ). In male rats, 5 and $10 \mathrm{~g} / \mathrm{L}$ creatine supplementation resulted in higher Slc6a8 expression in iWAT (Figure 4C). Finally, creatine content was examined in the adipose depots of the $10 \mathrm{~g} / \mathrm{L}$ groups and compared to the control groups. Creatine content was measured with a commercially available assay kit and was performed as outlined in the assay kit instructions (Biovision, Catalog \#K635-100). Creatine content 
was higher in female and male iWAT within the $10 \mathrm{~g} / \mathrm{L}$ dose with no differences in the other adipose depots (Figure 4D).

A. Females

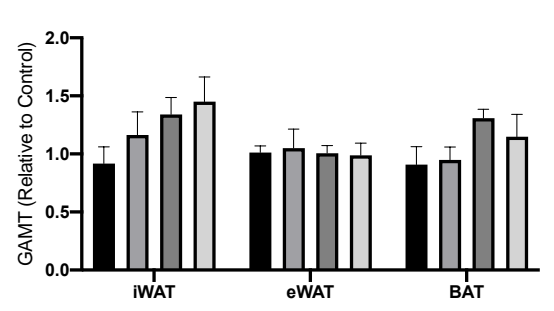

B.

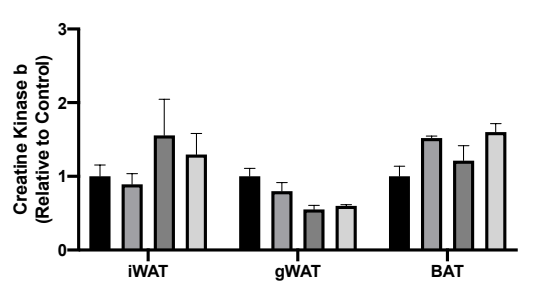

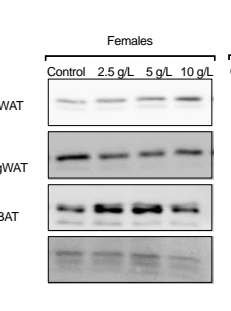

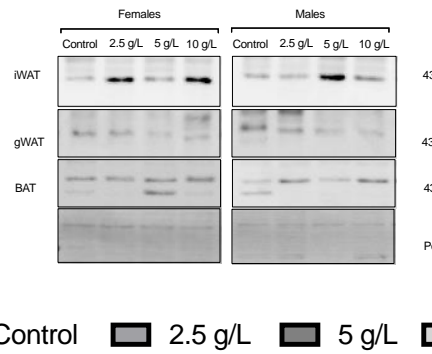

Males
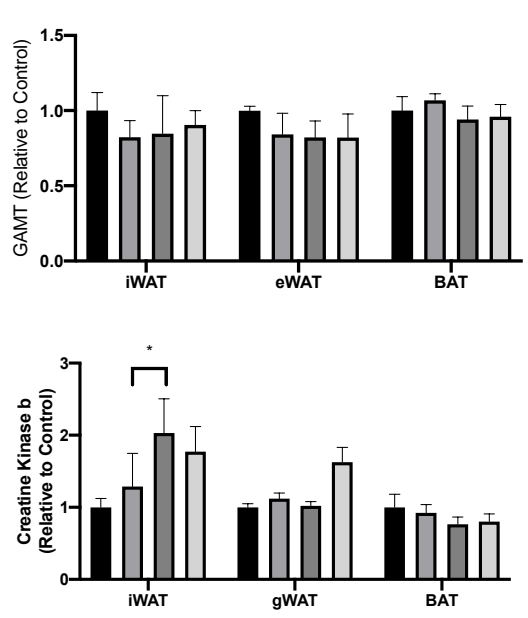

$10 \mathrm{~g} / \mathrm{L}$

C. Females

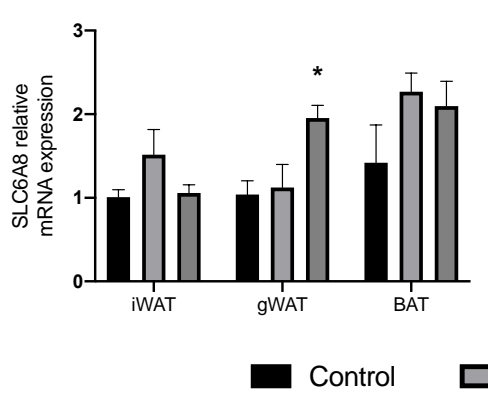

Males

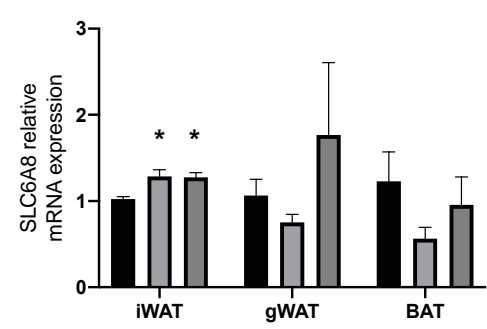

$5 \mathrm{~g} / \mathrm{L}$
D.

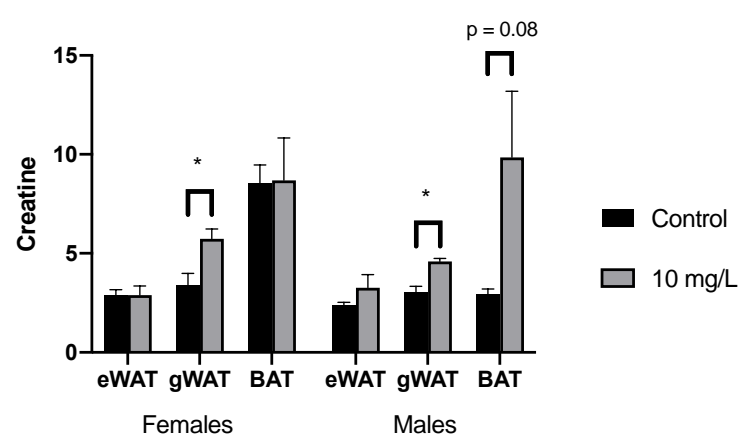

Figure 4. Adipose tissue markers of creatine uptake and metabolism. (A) Adipose tissue depot GAMT protein content in female (left) and male (right) rats. (B) Creatine kinase B content. (C) Slc6A8 mRNA expression. (D) Creatine content. Data were analyzed by ANOVA and are presented as mean $\pm \mathrm{SEM},{ }^{*}$ denotes significantly different from control group, $p<0.05$.

\section{Discussion}

Futile creatine cycling has been identified as a mechanism involved in adipose tissue browning and thermogenesis [14,20-24]. This study examined the potential for creatine supplementation to alter mitochondrial markers in WAT in both male and female SpragueDawley rats. Our novel results demonstrate that male and female WAT have a depot specific and sex dependent response to creatine supplementation. Creatine supplementation resulted in an increased creatine content in iWAT in the female and male rats. This was accompanied by increased mitochondrial markers (COXIV, PDH-E1alpha, and cytochrome C) in female rats. No effects on mitochondrial protein markers were observed in male iWAT depots, despite an increase in creatine content. Alternatively, there were no changes in response to creatine supplementation in female rat gWAT, however in male rats, creatine supplementation increased mitochondrial markers (COXIV and PDH-E1alpha) in gWAT. Together, these results highlight creatine supplementation as a potential means to increase WAT mitochondrial content and further highlight the importance of examining sex differences when studying adipose tissue.

Historically, adipose mediated thermogenesis has focused on the role of UCP1, however, it has become apparent that there are UCP1 independent mechanisms that contribute to adipose tissue browning and thermogenesis. Creatine supports energy expenditure in 
adipocytes and recent work has highlighted a role for futile creatine cycling in adipose tissue thermogenesis $[14,19-24,36,37]$. The potential underlying mechanisms that link creatine to thermogenic respiration have been recently reviewed [8,37]. However, it was not until recently that work has shed some light into the exact underlying mechanisms. Briefly, it has been determined that creatine elicits a substrate cycle of mitochondrial ATP turnover in a sub-stoichiometric fashion [37] and that the recruitment of mitochondrial CKB plays a crucial role in the transfer of phosphate between ATP and creatine [24]. Recently, TNAP was also identified to play an important role [25]. In thermogenic adipocytes, TNAP localizes to mitochondria where it initiates the futile cycling of creatine dephosphorylation and phosphorylation [25]. The potential of dietary creatine supplementation to stimulate adipose tissue browning has yet to be fully investigated. Kazak et al. examined creatine supplementation in Adipo-Gatm KO mice and found that supplementation rescued impaired adrenergic thermogenesis in these mice [22]. Here, we demonstrated that 8 weeks of creatine supplementation results in increased mitochondrial markers in WAT depots with no change in UCP1 content. This is an important and novel finding as it suggests that dietary creatine may be a means to improve adipose tissue health and possibly increase thermogenesis, independent of UCP1. One limitation of this work is the lack of functional outcomes at the tissue and whole-body level. Future work should determine if these increases in mitochondrial protein content result in enhanced mitochondria respiration and in turn if this enhances whole-body energy expenditure. While there were no differences in body mass amongst groups at the end of the intervention, it is possible that longer term supplementation or supplementation in conjunction with exercise training may result in significant reductions in body mass.

Interestingly, the observed increases in mitochondrial markers were sex- and depotspecific. Our findings show that in female rats, 8 weeks of creatine supplementation resulted in mitochondrial adaptations in inguinal subcutaneous WAT with no changes in the visceral WAT, while the opposite was true for male rats. Much information about adipose tissue depots specific differences has accumulated over the past few decades. It is known that the type of adipose tissue and the location in which it accumulates is important with regard to disease risk. For example, the accumulation of visceral WAT is associated with an increased risk of insulin resistance, type 2 diabetes, dyslipidemia, and atherosclerosis [38,39], while subcutaneous WAT is associated with higher insulin sensitivity and a reduced risk of type 2 diabetes [40-42]. The underlying mechanisms for the varying responses and metabolic effects of subcutaneous and visceral fat are most likely due to unique properties within the depots. Subcutaneous and visceral adipocytes develop from different progenitor cell lines, differentiate at varying rates, and can develop unique gene expression profiles [43,44]. For example, the expression of PRDM16, a transcription coregulatory protein responsible for adipose tissue browning, is much higher in subcutaneous WAT compared to visceral WAT [45]. It is known that beige cells are found interspersed in the WAT of humans and rodents [46-48], and the browning occurs predominantly in subcutaneous WAT. These differences between adipose tissue depots could account for the diverse responses to dietary creatine supplementation in our study. However, further investigation is needed to fully determine the molecular mechanisms underlying the creatine-induced mitochondrial changes and how this regulation is specific to each adipose tissue depot in both sexes. Future studies should explore differences in creatine transporter content and uptake across depots and sexes.

Animal models have demonstrated that sex and sex hormones can influence adipose tissue development, adipogenesis, gene expression profiles regulating insulin resistance and lipolysis, as well as the inflammatory tone and remodeling responses to obesity [49]. It is possible that the observed differences in response to creatine supplementation are due to circulating sex hormones. Previous work has shown that subcutaneous WAT has a higher concentration of estrogen receptors and progesterone receptors compared to androgen receptors in females. In contrast, visceral WAT has a higher concentration of androgen receptors $[49,50]$. This differential expression of sex hormone receptors could 
have influenced the response to creatine supplementation observed here in female and male rats. Interestingly, in differentiated 3T3L1 adipocytes, estradiol stimulated the specific activity of creatine kinase [51,52]. This highlights the differential response in adipose depots across sexes and together with our results sets the groundwork for future work in the area.

In the current study, mRNA analysis was conducted to examine if creatine supplementation had an effect on the expression of the creatine transporter (Slc6a8). Differences were demonstrated in a sex- and depot-specific manner. Females exhibited increases of the Slc6a8 gene within the gWAT adipose depot, whereas males exhibited this increase in the iWAT depot. This finding is compelling as it contrasts our other findings, which demonstrated that females experienced mitochondrial protein increases in iWAT and males in the gWAT. As explained previously, subcutaneous iWAT has higher concentrations of estrogen receptors in females, whereas visceral gWAT has higher concentrations of androgen receptors. Therefore, it is possible this finding may be explained as an adaptive physiological response; the Slc6a8 gene may be upregulated in female gWAT depots and male iWAT depots in an attempt to produce equal physiological responses among different adipose depots within the same rat, however, this is purely speculative.

The current study provides new information demonstrating the potential of dietary creatine supplementation on improving WAT health and increasing mitochondrial markers. Of note are the novel sex- and depot- specific responses to creatine supplementation. These highlight the importance of examining sex-differences in adipose tissue. Future work should explore the depot- and sex- specific responses to creatine. Importantly, the results presented here highlight the efficacy of creatine supplementation to increase mitochondrial proteins and highlight the potential as a preventative or therapeutic treatment for obesity and related metabolic diseases.

Author Contributions: Conceptualization, B.D.R. and R.E.K.M.; methodology, C.R.R., M.S.F., T.C.D., J.E.M.; formal analysis, C.R.R., M.S.F., T.C.D., J.E.M.; resources, B.D.R. and R.E.K.M.; data curation, C.R.R., M.S.F., T.C.D., J.E.M.; writing-original draft preparation, C.R.R.; writing—review and editing, M.S.F., T.C.D., J.E.M., B.D.R., R.E.K.M.; supervision, B.D.R. and R.E.K.M.; funding acquisition, B.D.R. and R.E.K.M. All authors have read and agreed to the published version of the manuscript.

Funding: This work was supported by Brock University. C. Ryan and M. Finch are supported by an Ontario Graduate Scholarship (OGS).

Institutional Review Board Statement: The study was conducted according to the guidelines of the Declaration of Helsinki, and approved by the Institutional Review Board of Brock University.

Informed Consent Statement: Not applicable.

Data Availability Statement: Data available upon request.

Conflicts of Interest: The authors declare no conflict of interest.

\section{References}

1. Berlet, H.H.; Bonsmann, I.; Birringer, H. Occurrence of free creatine, phosphocreatine and creatine phosphokinase in adipose tissue. Biochim. Biophys. Acta 1976, 437, 166-174. [CrossRef]

2. Bertholet, A.M.; Kazak, L.; Chouchani, E.T.; Bogaczynska, M.G.; Paranjpe, I.; Wainwright, G.L.; Betourne, A.; Kajimura, S.; Spiegelman, B.M.; Kirichok, Y. Mitochondrial Patch Clamp of Beige Adipocytes Reveals UCP1-Positive and UCP1-Negative Cells Both Exhibiting Futile Creatine Cycling. Cell Metab. 2017, 25, 811-822.e4. [CrossRef]

3. Buford, T.W.; Kreider, R.B.; Stout, J.R.; Greenwood, M.; Campbell, B.; Spano, M.; Ziegenfuss, T.; Lopez, H.; Landis, J.; Antonio, J. International Society of Sports Nutrition position stand: Creatine supplementation and exercise. J. Int. Soc. Sports Nutr. 2007, 4, 6. [CrossRef]

4. Cannon, B.; Nedergaard, J. Brown adipose tissue: Function and physiological significance. Physiol. Rev. 2004, 84, 277-359. [CrossRef] [PubMed]

5. Chang, E.; Varghese, M.; Singer, K. Gender and Sex Differences in Adipose Tissue. Curr. Diabetes Rep. 2018, 18, 69. [CrossRef]

6. Choi, C.H.J.; Cohen, P. Adipose crosstalk with other cell types in health and disease. Exp. Cell Res. 2017, 360, 6-11. [CrossRef] [PubMed] 
7. Chouchani, E.T.; Kazak, L.; Spiegelman, B.M. New Advances in Adaptive Thermogenesis: UCP1 and Beyond. Cell Metab. 2019, 29, 27-37. [CrossRef]

8. Cinti, S. Transdifferentiation properties of adipocytes in the adipose organ. Am. J. Physiol. Endocrinol. Metab. 2009, 297, E977-E986. [CrossRef] [PubMed]

9. Cohen, P.; Levy, J.D.; Zhang, Y.; Frontini, A.; Kolodin, D.P.; Svensson, K.J.; Lo, J.C.; Zeng, X.; Ye, L.; Khandekar, M.J.; et al. Ablation of PRDM16 and beige adipose causes metabolic dysfunction and a subcutaneous to visceral fat switch. Cell 2014, 156, 304-316. [CrossRef] [PubMed]

10. Cooper, R.; Naclerio, F.; Allgrove, J.; Jimenez, A. Creatine supplementation with specific view to exercise/sports performance: An update. J. Int. Soc. Sports Nutr. 2012, 9, 33. [CrossRef]

11. Enerback, S. The origins of brown adipose tissue. N. Engl. J. Med. 2009, 360, 2021-2023. [CrossRef] [PubMed]

12. Fedorenko, A.; Lishko, P.V.; Kirichok, Y. Mechanism of fatty-acid-dependent UCP1 uncoupling in brown fat mitochondria. Cell 2012, 151, 400-413. [CrossRef]

13. Gesta, S.; Bluher, M.; Yamamoto, Y.; Norris, A.W.; Berndt, J.; Kralisch, S.; Boucher, J.; Lewis, C.; Kahn, C.R. Evidence for a role of developmental genes in the origin of obesity and body fat distribution. Proc. Natl. Acad. Sci. USA 2006, 103, 6676-6681. [CrossRef] [PubMed]

14. Granneman, J.G.; Burnazi, M.; Zhu, Z.; Schwamb, L.A. White adipose tissue contributes to UCP1-independent thermogenesis. Am. J. Physiol. Endocrinol. Metab. 2003, 285, E1230-E1236. [CrossRef]

15. Grimpo, K.; Volker, M.N.; Heppe, E.N.; Braun, S.; Heverhagen, J.T.; Heldmaier, G. Brown adipose tissue dynamics in wild-type and UCP1-knockout mice: In vivo insights with magnetic resonance. J. Lipid Res. 2014, 55, 398-409. [CrossRef] [PubMed]

16. Hirshman, M.F.; Wardzala, L.J.; Goodyear, L.J.; Fuller, S.P.; Horton, E.D.; Horton, E.S. Exercise training increases the number of glucose transporters in rat adipose cells. Am. J. Physiol. 1989, 257, E520-E530. [CrossRef] [PubMed]

17. Ikeda, K.; Kang, Q.; Yoneshiro, T.; Camporez, J.P.; Maki, H.; Homma, M.; Shinoda, K.; Chen, Y.; Lu, X.; Maretich, P.; et al. UCP1-independent signaling involving SERCA2b-mediated calcium cycling regulates beige fat thermogenesis and systemic glucose homeostasis. Nat. Med. 2017, 23, 1454-1465. [CrossRef]

18. Ipsiroglu, O.S.; Stromberger, C.; Ilas, J.; Hoger, H.; Muhl, A.; Stockler-Ipsiroglu, S. Changes of tissue creatine concentrations upon oral supplementation of creatine-monohydrate in various animal species. Life Sci. 2001, 69, 1805-1815. [CrossRef]

19. Kazak, L.; Chouchani, E.T.; Jedrychowski, M.P.; Erickson, B.K.; Shinoda, K.; Cohen, P.; Vetrivelan, R.; Lu, G.Z.; Laznik-Bogoslavski, D.; Hasenfuss, S.C.; et al. A creatine-driven substrate cycle enhances energy expenditure and thermogenesis in beige fat. Cell 2015, 163, 643-655. [CrossRef]

20. Kazak, L.; Chouchani, E.T.; Lu, G.Z.; Jedrychowski, M.P.; Bare, C.J.; Mina, A.I.; Kumari, M.; Zhang, S.; Vuckovic, I.; LaznikBogoslavski, D.; et al. Genetic Depletion of Adipocyte Creatine Metabolism Inhibits Diet-Induced Thermogenesis and Drives Obesity. Cell Metab. 2017, 26, 693. [CrossRef]

21. Kazak, L.; Rahbani, J.F.; Samborska, B.; Lu, G.Z.; Jedrychowski, M.P.; Lajoie, M.; Zhang, S.; Ramsay, L.C.; Dou, F.Y.; Tenen, D.; et al. Ablation of adipocyte creatine transport impairs thermogenesis and causes diet-induced obesity. Nat. Metab. 2019, 1, 360-370. [CrossRef]

22. Kopecky, J.; Clarke, G.; Enerback, S.; Spiegelman, B.; Kozak, L.P. Expression of the mitochondrial uncoupling protein gene from the aP2 gene promoter prevents genetic obesity. J. Clin. Investig. 1995, 96, 2914-2923. [CrossRef]

23. Kreider, R.B. Effects of creatine supplementation on performance and training adaptations. Mol. Cell. Biochem. 2003, 244, 89-94. [CrossRef]

24. Kreider, R.B.; Melton, C.; Rasmussen, C.J.; Greenwood, M.; Lancaster, S.; Cantler, E.C.; Milnor, P.; Almada, A.L. Long-term creatine supplementation does not significantly affect clinical markers of health in athletes. Mol. Cell. Biochem. 2003, 244, 95-104. [CrossRef]

25. Livak, K.J.; Schmittgen, T.D. Analysis of relative gene expression data using real-time quantitative PCR and the $2^{-\Delta \Delta C}{ }_{T}$ Method. Methods 2001, 25, 402-408. [CrossRef] [PubMed]

26. Lowell, B.B.; S-Susulic, V.; Hamann, A.; Lawitts, J.A.; Himms-Hagen, J.; Boyer, B.B.; Kozak, L.P.; Flier, J.S. Development of obesity in transgenic mice after genetic ablation of brown adipose tissue. Nature 1993, 366, 740-742. [CrossRef]

27. Macotela, Y.; Boucher, J.; Tran, T.T.; Kahn, C.R. Sex and depot differences in adipocyte insulin sensitivity and glucose metabolism. Diabetes 2009, 58, 803-812. [CrossRef] [PubMed]

28. MacPherson, R.E.; Baumeister, P.; Peppler, W.T.; Wright, D.C.; Little, J.P. Reduced cortical BACE1 content with one bout of exercise is accompanied by declines in AMPK, Akt, and MAPK signaling in obese, glucose-intolerant mice. J. Appl. Physiol. 2015, 119, 1097-1104. [CrossRef] [PubMed]

29. McKie, G.L.; Wright, D.C. Biochemical adaptations in white adipose tissue following aerobic exercise: From mitochondrial biogenesis to browning. Biochem. J. 2020, 477, 1061-1081. [CrossRef]

30. Misra, A.; Garg, A.; Abate, N.; Peshock, R.M.; Stray-Gundersen, J.; Grundy, S.M. Relationship of anterior and posterior subcutaneous abdominal fat to insulin sensitivity in nondiabetic men. Obes. Res. 1997, 5, 93-99. [CrossRef]

31. Muller, S.; Balaz, M.; Stefanicka, P.; Varga, L.; Amri, E.Z.; Ukropec, J.; Wollscheid, B.; Wolfrum, C. Proteomic Analysis of Human Brown Adipose Tissue Reveals Utilization of Coupled and Uncoupled Energy Expenditure Pathways. Sci. Rep. 2016, 6, 30030. [CrossRef] 
32. Dunham, T.C.; Murphy, J.E.; MacPherson, R.E.; Fajardo, V.A.; Ward, W.E.; Roy, B.D. Sex-and tissue-dependent creatine uptake in response to different creatine monohydrate doses in male and female Sprague-Dawley rats. Appl. Physiol. Nutr. Metab. 2021. [CrossRef]

Nair, A.B.; Jacob, S. A simple practice guide for dose conversion between animals and human. J. Basic Clin. Pharm. 2016, 7, 27-31. [CrossRef]

33. Petrovic, N.; Walden, T.B.; Shabalina, I.G.; Timmons, J.A.; Cannon, B.; Nedergaard, J. Chronic peroxisome proliferator-activated receptor $\gamma(\operatorname{PPAR} \gamma)$ activation of epididymally derived white adipocyte cultures reveals a population of thermogenically competent, UCP1-containing adipocytes molecularly distinct from classic brown adipocytes. J. Biol. Chem. 2010, 285, 7153-7164. [CrossRef] [PubMed]

34. Rahbani, J.F.; Roesler, A.; Hussain, M.F.; Samborska, B.; Dykstra, C.B.; Tsai, L.; Jedrychowski, M.P.; Vergnes, L.; Reue, K.; Spiegelman, B.M.; et al. Creatine kinase B controls futile creatine cycling in thermogenic fat. Nature 2021, 590, 480-485. [CrossRef] [PubMed]

35. Roesler, A.; Kazak, L. UCP1-independent thermogenesis. Biochem. J. 2020, 477, 709-725. [CrossRef] [PubMed]

36. Rosenwald, M.; Perdikari, A.; Rulicke, T.; Wolfrum, C. Bi-directional interconversion of brite and white adipocytes. Nat. Cell Biol. 2013, 15, 659-667. [CrossRef] [PubMed]

37. Sebo, Z.L.; Rodeheffer, M.S. Assembling the adipose organ: Adipocyte lineage segregation and adipogenesis in vivo. Development 2019, 146, dev172098. [CrossRef] [PubMed]

38. Snijder, M.B.; Dekker, J.M.; Visser, M.; Bouter, L.M.; Stehouwer, C.D.; Kostense, P.J.; Yudkin, J.S.; Heine, R.J.; Nijpels, G.; Seidell, J.C. Associations of hip and thigh circumferences independent of waist circumference with the incidence of type 2 diabetes: The Hoorn Study. Am. J. Clin. Nutr. 2003, 77, 1192-1197. [CrossRef] [PubMed]

39. Somjen, D.; Tordjman, K.; Waisman, A.; Mor, G.; Amir-Zaltsman, Y.; Kohen, F.; Kaye, A.M. Estrogen stimulation of creatine kinase B specific activity in 3T3L1 adipocytes after their differentiation in culture: Dependence on estrogen receptor. J. Steroid Biochem. Mol. Biol. 1997, 62, 401-408. [CrossRef]

40. Stallknecht, B.; Vinten, J.; Ploug, T.; Galbo, H. Increased activities of mitochondrial enzymes in white adipose tissue in trained rats. Am. J. Physiol. 1991, 261, E410-E414. [CrossRef] [PubMed]

41. Sun, Y.; Rahbani, J.F.; Jedrychowski, M.P.; Riley, C.L.; Vidoni, S.; Bogoslavski, D.; Hu, B.; Dumesic, P.A.; Zeng, X.; Wang, A.B.; et al Mitochondrial TNAP controls thermogenesis by hydrolysis of phosphocreatine. Nature 2021, 593, 580-585. [CrossRef]

42. Tchkonia, T.; Lenburg, M.; Thomou, T.; Giorgadze, N.; Frampton, G.; Pirtskhalava, T.; Cartwright, A.; Cartwright, M.; Flanagan, J.; Karagiannides, I.; et al. Identification of depot-specific human fat cell progenitors through distinct expression profiles and developmental gene patterns. Am. J. Physiol. Endocrinol. Metab. 2007, 292, E298-E307. [CrossRef]

43. Townsend, L.K.; Wright, D.C. Looking on the "brite" side exercise-induced browning of white adipose tissue. Pflug. Arch. Eur. J. Physiol. 2019, 471, 455-465. [CrossRef]

44. Tran, T.T.; Yamamoto, Y.; Gesta, S.; Kahn, C.R. Beneficial effects of subcutaneous fat transplantation on metabolism. Cell Metab. 2008, 7, 410-420. [CrossRef] [PubMed]

45. Trayhurn, P. Endocrine and signalling role of adipose tissue: New perspectives on fat. Acta Physiol. Scand. 2005, 184, 285-293. [CrossRef] [PubMed]

46. Ukropec, J.; Anunciado, R.P.; Ravussin, Y.; Hulver, M.W.; Kozak, L.P. UCP1-independent thermogenesis in white adipose tissue of cold-acclimated Ucp1 $1^{-/-}$mice. J. Biol. Chem. 2006, 281, 31894-31908. [CrossRef] [PubMed]

47. Van Loon, L.J.; Oosterlaar, A.M.; Hartgens, F.; Hesselink, M.K.; Snow, R.J.; Wagenmakers, A.J. Effects of creatine loading and prolonged creatine supplementation on body composition, fuel selection, sprint and endurance performance in humans. Clin. Sci. 2003, 104, 153-162. [CrossRef]

48. Veniant, M.M.; Sivits, G.; Helmering, J.; Komorowski, R.; Lee, J.; Fan, W.; Moyer, C.; Lloyd, D.J. Pharmacologic Effects of FGF21 Are Independent of the "Browning" of White Adipose Tissue. Cell Metab. 2015, 21, 731-738. [CrossRef]

49. Wakatsuki, T.; Hirata, F.; Ohno, H.; Yamamoto, M.; Sato, Y.; Ohira, Y. Thermogenic responses to high-energy phosphate contents and/or hindlimb suspension in rats. Jpn. J. Physiol. 1996, 46, 171-175. [CrossRef] [PubMed]

50. Wang, Y.; Rimm, E.B.; Stampfer, M.J.; Willett, W.C.; Hu, F.B. Comparison of abdominal adiposity and overall obesity in predicting risk of type 2 diabetes among men. Am. J. Clin. Nutr. 2005, 81, 555-563. [CrossRef]

51. Yamashita, H.; Ohira, Y.; Wakatsuki, T.; Yamamoto, M.; Kizaki, T.; Oh-ishi, S.; Ohno, H. Increased growth of brown adipose tissue but its reduced thermogenic activity in creatine-depleted rats fed $\beta$-guanidinopropionic acid. Biochim. Biophys. Acta 1995, 1230, 69-73. [CrossRef]

52. Zhang, C.; Rexrode, K.M.; van Dam, R.M.; Li, T.Y.; Hu, F.B. Abdominal obesity and the risk of all-cause, cardiovascular, and cancer mortality: Sixteen years of follow-up in US women. Circulation 2008, 117, 1658-1667. [CrossRef] [PubMed] 